\title{
Alternative Dispute Resolution and the Albanian Legal Reality
}

\author{
Phd. Candidate, Artan Spahiu
}

\author{
Lecturer at the Law Department \\ Faculty of Economy, "A.Xhuvani" University, Elbasan, Albania \\ phone: 00355 694070009; email: artan_spahiu@yahoo.com
}

\section{Doi:10.5901/mjss.2013.v4n10p146}

\begin{abstract}
Desire and ability to mediate and to solve conflicts through conciliation is a national asset for any country. Every human society shows the development stage of its citizenry inter alia through the self-regulatory mechanisms of disputes arising within its members. History has shown that even within albanian society have been existed such mechanisms which have regulated coexistence for centuries. Further more, the albanian tradition reminds us that the institution of dispute settlement through conciliation is deeply rooted in our lives and in our good habits. In terms of economic development, it is time that this tradition of extrajudicial settlement of disputes to be provided on professional level, affecting more the legal aspects. The state court, which is traditionally known as the place where all conflicts are resolved, should be seen increasingly as an alternative. Besides its, other important alternatives of conflict resolution should be focused by the law, such as mediation and arbitration. Therefore, this article, through the method of interpretative analysis, aims to present an overview of the albanian reality of these alternative legal means, trying to highlight the legal framework as well as the judicial practice. It will attempt to clarify the problematic issues, addressed by the domestic law in this area and the necessity for eventual changes. Implementation of contemporary legal instruments in accordance with the international trend, especially focused on the arbitration institute, will certainly offer a good service to the integration process of the albanian economy.
\end{abstract}

\section{Conciliation and mediation in the albanian legal framework.}

\subsection{The conciliation on disputes resolution.}

While the careful drafting of contracts will reduce their frequency, disputes will at times arise. Therefore, it is essential that they be managed and resolved efficiently. In order to do so, parties must be familiar with their dispute resolution options $^{1}$. The emergence of disputes has led naturally to different practices and experiences for their solution. The most common among these alternatives are mediation and conciliation.

Conciliation differs from mediating from the fact that the conciliator is a third person independent from the parties. In a reconciliation process, the conciliator assists the parties to reach a solution to their dispute, so that they both are satisfied by the outcome of the process. A possible definition of conciliation is: the process by which a third party assists the opposing parties to understand their conflict cause and to solve the dispute, resulting from it, on the basis of respect for each other and on the need to focus on opportunities of the future for living and working together. Conciliation means a process, whether referred to by the expression conciliation, mediation or an expression of similar import, whereby parties request a third person or persons ("the conciliator") to assist them in their attempt to reach an amicable settlement of their dispute arising out of or relating to a contractual or other legal relationship. The conciliator does not have the authority to impose upon the parties a solution to the dispute? ${ }^{2}$.

The conciliation procedures in Albanian legislation, is regulated by various provision of the Code of Civil Procedure, which recognize the duty of the different instances of judicial sistem to resolve initially the disputes between the parties through conciliation ${ }^{3}$. For example, the article 25 of the Code of Civil Procedure provides that "it's the duty of the court to make an effort to reconcile the parties in a dispute". If the agreement is reached, an official record must be

\footnotetext{
1 Dispute Resolution for the 21st Century, Wipo Arbitration and Mediation Center; http://www.wipo.int/amc

2 Model Law on International Commercial Conciliation of the United Nations Commission on International Trade Law (UNCITRAL) 2002, United Nations Documents, A/RES/57/18, article 1(3).

${ }^{3}$ Code of Civil Procedure (CCP), article 25, 108, 158/b, 361, 362, 461.
} 
hold by the court, which should be signed by the parties and on this basis the court makes the decision on the issue, which is subject to appeal, in other instances the of the judiciary system. ${ }^{4}$

What makes the albanian legal framework special, regarding the conciliation, is that the conciliator role is not exercised by a third party, independent from the public court system, and if this "third party" really exists in practise its role is "invisible". It is the state court which keeps the record of decision for conciliation and seals the agreement. Meanwhile, refering to the international practices, the dispute resolution through conciliation refers to the intervention of a third person completely independent of the parties and public courts.

It is evident that albanian law recognizes to the conciliation process a material jurisdiction broader than that of arbitration. Specifically, the conciliation can be used for resolving marital disputes ${ }^{5}$ while the arbitration can not be used in these cases. Due to the extensive use of this instrument, some important international trade organisations have made efforts to harmonize legislation in the field of dispute resolution, in accordance with international trade. It is worth mentioning as illustration, the UNCITRAL Model Law on International Commercial Conciliation, published in $2002^{6}$.

\subsection{The legal reform on disputes resolution by mediation.}

In different historical periods in Albania, the mediation of disputes is conducted by various institutions and mainly by: assemblies, elders, the village leader, courts of villages and neighborhoods, religious institutions, social organizations, committees for reconciliation of blood feuds, offices for reconciliation in the field of labor disputes, ect. Institutionalization by law of the mediation process in Albania, after 1997, shows not only the objectives and goals of civil society, but also of the lawmaking political groups in order to identify mediation as an important alternative dispute resolution. The law no.10385, dated 24.2.2011 "On mediation in resolving disputes"8 constitutes a significant step towards a more advanced stage.

Mediation is the attempt to resolve a legal dispute through active participation of a third party (mediator) who wants to find points of contact between the parties in conflict, so they can agree on a fair result. Albanian legislation defines mediation as an "out-of-court"9 and "independent"10 activity, exercised in accordance with the law and under the auspices of the Ministry of Justice. This definition coincides with the one presented today at the European Union area ${ }^{11}$.

Mediation is a process of social nature as well as a process of legal nature. This is because any conflict and disagreement carries both social and legal elements. The following analysis will stop at the provisions of the albanian law on mediation, explaining concepts and expressions used by it.

a. Mediation is an out-of-court activity. This expression means the two legal situations: (1) when mediation is directly chosen by the parties as an alternative, without using any other alternative (litigation, arbitration, etc.), and (2) the situation when the dispute has begun to be resolved by a judicial, administrative or arbitral tribunal and the parties consider to leave it, in order to use the mediation alternative. In this case, the process is suspended until the estimation whether the parties will reach a conciliation agreement or not. This means that, in terms of law, the mediation service is realized with the help of subjects with no judicial authority, which are simply middlemen meeting the requirements of this law.

\footnotetext{
${ }^{4}$ Idem, art.158(b).

5 Idem, art.361 and 362.

${ }^{6}$ Resolution adopted by the General Assembly on 52nd plenary meeting, 19 November 2002 (A/57/562 and Corr.1) - The General Assembly, Recommends that all States give due consideration to the enactment of the Model Law, in view of the desirability of uniformity of the law of dispute settlement procedures and the specific needs of international commercial conciliation practice.

${ }^{7}$ see law no.8465, dated 11.3.1999 "On reconciliation of disputes" and the law no.9090, dated 26.6.2003 "On mediation to resolve disputes".

${ }^{8}$ Aligned with Directive 2008/52/EC "On certain aspects of mediation in civil and commercial matters", no.CELEX 3200810052.

${ }^{9}$ Law no.10385 "On mediation in resolving disputes", art.1(1): Mediation is an out-of-court activity, in which the parties seek resolution of a dispute through a neutral third party (mediator), in order to reach a mutually acceptable solution to the dispute and which does not conflict with the law.

${ }^{10} \mathrm{Idem}$, art.1(2): Mediation to resolve the dispute by conciliation is an independent activity, exercised in accordance with the law and under the auspices of the Ministry of Justice.

${ }^{11}$ Green Paper "On alternative dispute resolution in civil and commercial law", presented by the Commission; Brussels, 19.04.2002, $\operatorname{COM}(2002) 196$ final, p.6, par.2 : "Alternative methods of dispute resolution are defined as out-of-court dispute resolution processes conducted by a neutral third party, excluding arbitration proper".
} 
b. Mediation is an independent activity. The independence of this process implies that mediation is exercised by private entities as natyral persons as well as legal person, organized in the form of non-profit or for-profit organizations such as associations, centers, foundations, associations, and others. This alternative process is not carried out by public entities or by the public administration institutions, such as the courts, prosecutors, or police authorities. It is part of private initiatives of natyral and legal entities to provide mediation services to resolve the dispute with the help of a third person - the mediator.

c. Mediation is exercised under the auspices of the Ministry of Justice. Mediation is a process that after the $90^{\text {st }}$ has found its legal regulation in Albania by special laws, but it's the first time that this activity rises to a higher level regarding its professionalism. This is demonstrated by the fact that this extra activity is already performed under the auspices of the Ministry of Justice. Putting this mechanism in the care of such an authority is due to the law provision that mediation, to some disputes categories, becomes mandatory.

This process of ministry control implies the licensing process, the creation of the National Chamber of Mediators, creating a special register of licensed entities, adoption and promulgation of regulations to enable implementation of the law of mediation, ect. This marks an institutional backing and does not constrain the independence of performing mediation service by private entities.

d. The mediator should be a "third person". So the mediator is someone "outside" parties and the dispute. As such there can be no family ties or familiarity with the parties and any direct or indirect interest on the issue or the result of its solution.

e. The mediator is a "neutral" person. For this the mediator must truly be and also seem to be neutral, fair, equitable and non-biased, impartial, in some respects as towards the parties on the dispute, their interests and the options that the parties submit as alternative resolution of their dispute.

f. Mediation seeks a solution that "does not conflict with the law". Such a solution will be considered:

- First, a solution which may not be explicitly regulated by any law. So any solution for which the legislation remains silent, but the parties agree, will be considered in accordance with the law and not contrary to it.

- Second, a solution that is regulated by legal permitting provisions, namely the rules that leave parties free to decide by mutual agreement, contrary to what is stipulated in content provision and to arrange according to their will a legal relationship.

The main law principles on the mediation implementation are:

- Mediation takes place "at any time" required by the parties. The term "at any time" means that the conflict can be resolved through mediation even after it is filed in the court, prosecutor, police or in any other decisionmaker. Parties may address their dispute to the mediation, regardless of whether the case is being tried in the first instance, courts of appeal or the Supreme Court. "At any time" goes even further, mediation can be applied even after the court decision has become final and it's currently in executing stage.

- Mediation takes place only when the parties with their free will seek and accept the mediation process. The law obligates the judiciary system only to notify the parties for this alternative method and to orient them to mediation.

- Mediation in the civil, commercial, labor and family cases is comprehensive. This means that the parties are open to embrace the mediation alternative, generally in any case, excluding only those disputes, which are on mandatory jurisdiction of another body, as in the case of divorce, which can only be settled through a court decision.

\subsubsection{The scope of mediation alternative.}

Regarding the scope, the law defines the principles as well as the areas where mediation can be applied. Mediation covers a comprehensive field of conflicts of civil, family, labor and commercial nature as well as some disputes of criminal nature ${ }^{12}$. The only limitation regards the fact that the mediation process is not applicable in the case when at least one of the parties is a public legal person. In cases when the conflict has a contractual or property nature, but derives from an administrative contract, it is not part of the dispute which can be resolved through mediation. Also, in cases of conflict related to labor relations, when the employer is a public entity, the mediation process can not be applied to resolve the cause. In case that conflict arises from non contractual damage and the person who has caused the damage is a public entity, there is no place for mediation application despite the good will of the parties.

${ }^{12}$ Law no.10385 "On mediation in resolving disputes", art.2(2),(3) 
Mediation of disputes of property nature. The article 2 of the law on mediation uses the term "property conflict", which implies conflicts on "civil" and "commercial" matters. Under the law, in cases of property conflicts of all kinds, worth over 500 thousand LEK (ALL), the judge or the representative of the institution, that is examining the case, is obliged to invite the parties to pass to the mediation process, even if their judicial treatment has been commenced ${ }^{13}$. The term "property conflict" includes:

i. Conflicts of ownership: Disputes arising from the denial or infringement of the right of ownership to the owner; Disputes arising from the denial or infringement of the right of the lawful non-owner possessor.

ii. Contractual civil conflicts (conflicts arising from a breach of contract) and non contractual civil conflicts (conflicts of non-contractual caused damage).

iii. Commercial civil conflicts: Trade nature conflicts; Conflicts of failure of commercial contracts; Conflicts arising from the operation and management of companies.

Conflicts arising from labor relations. Disputes between employers and employees as social partners are integral in labor relations. The labor Code and other laws related to the employment field, provide mediation as an alternative dispute resolution. Refering to the provisions of the Labour Code, mediation is respectively regulated by the provisions of Chapter XVII (Articles 188-198) titled "mediation, conciliation, arbitration"14. However, between mediation based on the Labour Code and mediation process provided by the Law no.10385 "On mediation on resolving disputes", there are some significant changes.

Starting with the field of mediation, according to the Labor Code, mediation can only be applied on "collective conflicts"15. Consequently, the entities which are able to mediate are narrowly designated by the Labour Code. In contrast to the appointment of the mediator by law nr.10385 "On mediation in resolving disputes" (article 16), the Labor Code (article 188/a) provides that the mediator is appointed by the Minister of Labour and Social Affairs, or the administrative body within the public administration of that Ministry (State Labour Inspectorate). In addition to the above, the mediation pursuant to Labor Code is necessarily conducted on those disputes which are strictly set by the Labour Code $^{16}$ and by a mandatory procedure within a period of 10 days, specified in the Code.

In conclusion, the two alternatives of mediation process, regulated by different laws do not overlap or repeat each other but remain completely different.

Mediation on family disputes. In the albanian legal framework that has regulated the mediation institute from 1999 onwards, the field of family relationships did not miss from being part of the mediation option. In the law of 2011, the "care" towards family disputes is repeated. Further more, given the importance of the juvenile issues and marriage consequences, the law provides the context of a "obligatory" invitation ${ }^{17}$. This should not be understood as an imposition for the parties to obligatorily reach a settlement through mediation, but as an obligation of the court or other authority to inform via "invitation" the existence of this alternative and its advantages.

This does not mean that in other cases the court must not make such an invitation. Even in other cases the court has discretion to make such an invitation. But in the cases where the minors interests are included (or in other cases provided for in article 2/4) this "invitation" is not at the discretion of the court or state authority, but it's legally binding to be made. However, as mentioned above, this obligation of the court or another state body to invite the parties to mediation, should not be confused with the fact that mediation is a voluntary process. The incentive for settlement by mediation of family disputes is also an obligation deriving from international instruments ratified by Albania and does not affect at all the essence of mediation as a voluntary activity. Let's mention here the European Convention "On relations with children" (article 7/b) or the Hague Convention on parental responsibility (article 32).

\footnotetext{
${ }^{13}$ Law no.10385 "On mediation in resolving disputes", art.2(4): When put into motion for the resolution of a dispute in the civil, commercial, labor or family field, the court or the relevant state body, within the powers provided by law, obligatorily invite the parties to resolve through mediation, particularly, but not limited to, the dispute...c) of property character, on the claims up to 500 thousand,....

${ }^{14}$ see also articles 165, 168 of Labor Code.

${ }^{15}$ see article 188 of Labor Code on the meaning of "collective conflicts": conflicts between some employees, one or more organizations of employees, on the one hand, and one or more employers or one or more employers' organizations on the other side.

${ }^{16}$ Conflicts regarding the conclusion of collective labor agreements or disputes arising from the application or the breach of these contracts ("collective conflicts").

${ }^{17}$ Law no.10385 "On mediation in resolving disputes", art.2(4): When put into motion for the resolution of a dispute in the civil, commercial, labor or family field, the court or the relevant state body, within the powers provided by law, obligatorily invite the parties to resolve through mediation, particularly, but not limited to, the dispute a) on civil and family matters, when minors interests are included; b) on conciliation issues in divorce cases, provided for by Article 134 of Family Code; c) of property character, on the claims up to 500 thousand,....
} 
In the law "On mediation in resolving disputes", the legislator has synthesized the base general principles ${ }^{18}$ upon which the mediation service is established, based on the most advanced contemporary standarts. These principles, expressed in the albanian legislation, are important in practice, because they enable qualitative difference between mediation services with other dispute resolution forms, such as the judicial resolution of dispute, resolution by arbitration, administrative resolution, ect.

\section{Arbitration Institute and the Albanian legal framework.}

\subsection{Legal features of the state arbitration in Albania until the early 90 s.}

After the second world war, Albania as most of the countries of Eastern Europe, implemented the socialist economic system, based on Marxist theory and Soviet example of construction and operation of the economy. In this regard, in all these countries including Albania, a characteristic feature of the economic system was the creation of the institution of the State Arbitration.

In Albania, the state arbitration was established for the first time by decree-law no.443 dated July 2, 1947 "On resolving property disputes by state arbitration", which can be considered as the first organic law of this institution. During the 50 years of communist centralized economy, the state arbitration suffered some significant organizational and procedural changes ${ }^{19}$. The latest legislative development was the law nr.7424, dated 14.11.1990 "On state arbitration"20 and its implementing regulations.

Under this legal framework, the state arbitration was created as a permanent structure near the popular councils of sub-prefectures (later, popular councils of district), near the ministries and near the government. The disputes had to be examined by a council, composed of one arbitrator and two assistants.

The jurisdiction of state arbitration had a "double character": State arbitration had mandatory jurisdiction on reviewing of property disputes, contractual or pre-contractual, between institutions and state enterprises ("state vs. state" conflicts). It also had voluntary jurisdiction on reviewing of property conflicts between the institutions or state enterprises on the one hand and cooperatives, private enterprises, legal or natyral persons on the other hand ("state vs. private" conflicts), as well as between private entities themselves ("private vs. private" conflicts). In these cases (voluntary jurisdiction) conflicts could be examined by state arbitration only if the parties had specified it in a contract, or if they had reached a special agreement in writing for arbitration.

Regarding the manner of operation, the legal framework established that disputes were submitted to arbitration on request filed by the both parties ${ }^{21}$. At this point, the state arbitration presents similar features with classic institution of arbitration, the jurisdiction of which, as explained by the doctrine has contractual origin. The contractual theory explains why the essence of arbitration is contractual. First of all arbitration is based on the agreement of the parties. Where there is no arbitration agreement, no party can force another to arbitrate, except in the rare instances of compulsory arbitration. ${ }^{22}$

In state arbitration, the disputes could also be judged by the arbitration on its own motion (ex officio), or at the request of the entity where the arbitration structure was established (council of Ministers, ministries, central institutions, etc.), even at the request of the prosecutor ${ }^{23}$. Such a provision is a convincing proof of an obvious superiority of this institution compared with other mechanisms of resolving property disputes, even with the state courts.

\footnotetext{
${ }^{18}$ Law no.10385 "On mediation in resolving disputes", art.3: The main principles provided by the law are: the necessity to respect the equality of the parties in the mediation; principle of confidentiality; flexibility in many aspects of the process; transparency in terms of the right of parties to control and know all the elements of the mediation process; The right of the parties to engage in a mediation process and to offer and accept voluntarily, without imposition from the outside or from the mediator of the mode of dispute resolution in which they are involved; the impartiality of mediator, ect.

${ }_{19}^{19}$ Decree nr.1872 dated 07.05.1954 "On state arbitration"; Decree nr.5009 dated 10.11.1972 "On state arbitration", Official Journal 1972, No.6, page 75; Decree No.6927, dated 14.11.1984 "On amendments to the Decree No.5009 "On state arbitration", Official Journal 1984 , No.3, page 45.

20 Law nr.7424, dated 14.11.1990 "On state arbitration", Official Journal 1990, No.7, Page 240, date of publication 30.11.1990.

${ }^{21}$ Law nr.7424, dated 14.11.1990 "On state arbitration", art.11(a).

${ }^{22}$ Stone, Morris - "A Paradox in the Theory of Commercial Arbitration", 21 Arb.Journal. 1966, p.156; Wallace, E.V. - "Drafting a New York Arbitration Agreement" (No.3, N.Y.Continuing Legal Education), 1967.

${ }^{23}$ C.M. Decision no.26, dated 01.04.1991 "On approval of "Regulation of issues to be considered by the state arbitration", art.4: "The claims to the arbitration, should be examined with the necessary documents, .......The claims of ministers and other central institutions,
} 
The role of the State Arbitration was very active. Besides the fact of reviewing the issue on its own initiative, this institution had the power to exceed the limit of initial parties claims. So the final arbitral award may dispose on more issues than the claims addressed by the parties. Meanwhile if we refer to international law, even to the actual albanian domestic law on arbitration, such a provision does not exist. Under the actual domestic regulation, an arbitral award may be appealed to the court of appeal when ... the arbitral tribunal in its award has exceeded the claims for which it has been invested or has not stated on one of the main lawsuit claims. ${ }^{24}$

Regarding the competence, state arbitration imposed its jurisdiction as the only jurisdiction to resolve property contractual or non-contractual disputes between institutions, social organizations and state enterprises. So on the "state versus state" disputes, this type of arbitration was the only option and not an alternative solutions, as this mechanism is considered nowadays ${ }^{25}$. While the modern regulation of the arbitration institute, regarding the arbitration jurisdiction to resolve the dispute, provides an indispensable condition which is the will of the parties, expressed on arbitration agreement. Under the provisions of the albanian Code of Civil Procedure, an arbitration forum may have the jurisdiction to resolve the dispute only if it is met the necessary condition of the expression of the will of the parties through an arbitration agreement. ${ }^{26}$

Avoiding the confidentiality: An interesting fact regarding the trial proceedings in state arbitration was that the trial was provided to be performed, not only at the headquarters of the arbitration, but also as a popular show, for example in the presence of the technical council of the enterprise, in front of cooperative presidency, in the presence of other employees, etc. ${ }^{27}$. While one of the main principles of resolving disputes through arbitration, widely affirmed today by national and international legislations ${ }^{28}$, is the principle of confidentiality of the process, which describes the process as a private procedure. ${ }^{29}$

The arbitral award and its enforcement: The arbitral award was final and it was binding for the state Bank, financial bodies, as well as for bailiff offices. The enforcement of an arbitral award has been voluntarily performed by the parties within the appointed term, otherwise, the award has been compulsorily executed, based on the order of the execution issued from the arbitrator himself. ${ }^{30}$

\subsection{Arbitration and its current legal regulation in Albania.}

Albanian legislation recognizes and regulates the arbitration institute. The provisions relevant to arbitration are found in a special title of the Code of Civil Procedure ${ }^{31}$ (CCP) of the Republic of Albania. For the purposes of this law, arbitration is a special institute of civil procedural law for settling property disputes outside of judicial activity. It represents the will of the parties to a rapid and fair solution of these disputes, by entrusting the mission to one or more persons who organize and develop judgment adhering to the limits of the charged mission. The settling of the property disputes through arbitration enables the avoidance of a significant part of the judicial proceedings.

The arbitration chapter of the CCP focuses on the procedures for domestic arbitration and fails to provide rules of arbitral proceedings and court proceedings related to international arbitration. The CCP states that rules on international

the prosecutor and the executive committee of the district are accepted without these documents. In such cases, the arbitration determines what documents should be administered".

${ }^{24}$ Albanian Code of Civil Procedure, article 434.

25 The case "Marini vs. Albania", Appeal no.3738/02, Decision 18 December 2007, Strasbourg, par.10: "On an unspecified date, to obtain compensation, the applicant complained to the State Arbitration, which at the time was the competent body for disputes involving state-owned enterprises. On 7 May 1993, the State Arbitration recognised the validity of the 'Marin-Albplastik' company statute. Moreover, he ordered the state to pay the applicant ......".

${ }^{26}$ Albanian CCP, article 403 "Arbitration agreement": Can be judged by arbitration procedure only if there is an agreement between the parties, by which they agree to submit to arbitration disputes which have arisen or may arise out of a contract between them.

${ }^{27}$ C.M. Decision no.178, dated 24.10.1973 "On approval of the Regulation on the review of disputes by state arbitration"; Official Journal, year 1973 No.5, Page 79.

28 UNCITRAL Model Law on International Commercial Arbitration; art.20(1) "Place of arbitration"; The parties are free to agree on the place of arbitration. Failing such agreement, the place of arbitration shall be determined by the arbitral tribunal having regard to the circumstances of the case, including the convenience of the parties.

29 Its principal characteristics are: - arbitration is a mechanism for the settlement of disputes; - arbitration is consensual; - arbitration is a private procedure; - arbitration leads to a final and binding determination of the rights and obligations of the parties; United Nations Conference on Trade and Development, Dispute Settlement, International Commercial Arbitration; UNCTAD/EDM/Misc.232/Add.38.

30 Law nr.7424, dated 14.11.1990 "On state arbitration", art.28.

31 Law No.8116, dated 29 March 1996, as amended, Part II, Title IV “Arbitration", art. 400 - 439. 
arbitration shall be established by a separate law (art.439), a law which still has to be adopted in Albania. This obligation is not fulfilled since no special law on international arbitration has been approved. But the effect of this provision (article 439 ) is to issue the international arbitration outside influence of the regulation provided by articles 400-438 of the Code. These articles regulate all concepts pertaining to arbitration, for example the matters relating to the arbitration agreement, the arbitral forum choice, the law applicable to the arbitration agreement, the arbitration procedures, the civil court interventions in an arbitral process, the granting and enforcement of the arbitration awards, ect.

Other important provisions in the field of international arbitration are contained in Title III, Chapter IX of CCP, governing recognition and enforcement of foreign arbitral awards in Albania. Part of the albanian legal framework governing the arbitration are also the Convention "On the recognition and enforcement of foreign arbitral awards"32, otherwise known as the New York Convention, the most important multilateral treaty on international arbitration and the European Convention on Arbitration, also known as the Geneva Convention 33 .

However, despite the fact that current albanian legal framework enables the creation of a permanent or "ad hoc" arbitration court and provides a fair process, we can say that Albania has not yet a consolidated practice on alternative dispute resolution through arbitration mechanism. A part of this legal framework needs to be improved in the future. In this point we can mention the provision for the judgment on the merits by the Court of Appeal on the appealed arbitration awards, a fact which diminishes the importance of selecting a private arbitration court for trade disputes. The domestic law does not provide the autonomy of the arbitration clause from other terms of the main contract, not recognizing at all the principle of "Separability" ${ }^{34}$. It's also rather important for the domestic law to include the basic principle of confidentiality and privacy of the arbitration process, which will be a further guarantee for the parties in dispute.

In December 2002, in Albania was created a permanent arbitral forum at the Chamber of Commerce in Tirana, the Albanian Center of Commercial Mediation and Arbitration "MEDART", which was active until 2009 as a private and independent institution, established with the World Bank support. This center, throughout its modest activity, managed only a small number of cases and, regardless of its purpose, it failed to promote the arbitration service of dispute resolution in private sector of the albanian economy.

One of the main reasons was the fact that companies and businesses in Albania, in 2002 onwards, were generally characterized by a clear lack of confidence in the justice system and in particular in the justice of the albanian state courts. Consequently, it was almost impossible for these businesses to believe that a private judge or court could secure justice, which, as they believe, can be barely provided by the state.

Another factor ranked by lawyers, is the level of economic development. Arbitration is a very expensive process and albanian businesses have considered this investment for a private court as a luxury solution.

The lack of entities, which can promote the dispute resolution by arbitration, is another factor that has contributed to the delay in recognizing and development of this institution in Albania. Likewise, the lack of institutions which train professional arbitrators and the lack of permanent arbitration forums at the chambers of commerce, is another reason added to the argument that the albanian arbitration reflects today an almost undeveloped stage.

\section{Conclusions}

It is time that the well-known tradition of extrajudicial settlement of disputes to be provided on professional level, in the albanian internal legal framework. In this context, it is the drafting and adoption of the mediation legal framework by the Albanian Parliament. According to the albanian law, mediation is an "out-of-court" and "independent" activity, which covers a comprehensive field of conflicts of civil, family, labor and commercial nature as well as some disputes of criminal nature. The general principles of equality, confidentiality, flexibility, transparency, impartiality, ect. synthesized by the albanian law on mediation, are based on the most advanced contemporary standarts.

\footnotetext{
${ }^{32}$ Convention on the Recognition and Enforcement of Foreign Arbitral Awards was prepared and opened for signature on 10 June 1958 by the United Nations Conference on International Commercial Arbitration and entered into force on 7 June 1959. This convention has been effective in Albania since its ratification by the Albanian Parliament by law No.8688, dated 9.11.2000.

${ }^{33}$ The Geneva Convention was drafted by the UN Economic Commission for Europe, was signed in Geneva on 21 April 1961 and was entered into force on 7 January 1964. This convention has been effective in Albania since its ratification by the Albanian Parliament by law No.8687, dated 9.11.2000.

34 "Separability means that an arbitration clause shall be treated as an agreement independent of the other terms of the contract. As a consequence, a decision by the arbitral tribunal that the contract is null and void shall not entail ipso jure the invalidity of the arbitration clause"; Explanatory Note by the UNCITRAL Secretariat on the 1985 Model Law on International Commercial Arbitration as amended in 2006; Part II, par.25.
} 
In cases of labor disputes, the two alternatives of mediation process, regulated by two different laws (Labour Code and Law on Mediation) do not overlap or repeat each other but remain completely different. In some conflicts, specially those of family nature, given the importance of the juvenile issues and marriage consequences, the law provides the context of a "obligatory" invitation.

While the mediation alternative has gained its contemporary contours, not enough has been done to promote another alternative mechanism of dispute resolution: the arbitration. In fact, before the $90^{\mathrm{s}}$ the role of the State Arbitration was very active. The state arbitration in Albania was an resolving disputes institution engaged with much larger attributes than state courts exercise today. Its "double character" jurisdiction was expressed in its mandatory jurisdiction when reviewing "state versus state" conflicts. In these cases, the disputes could be judged by the state arbitration on its own motion. That's why the arbitration was characterized as the only option and not an alternative solution. This institution had also the power to exceed the limit of initial parties claims and the arbitration proceedings was often performed avoiding the confidentiality and consequently transforming the arbitration in a "public" procedure.

Whereas the current albanian legal framework enables the creation of a permanent or ad hoc arbitration court and also provides a fair process. Despite this, Albania has not yet a consolidated practice on alternative dispute resolution through arbitration. A part of this legal framework needs to be improved in the future. For example, the law provision that the Court of Appeal decides on the merits of the dispute is considered an obstacle to the parties orientation toward arbitration, because in any case they should bear in mind the possibility that, despite their will, at the end the dispute will be adjudicated in a state court.

The economic development in Albania, the frequency of trade relations between local traders and foreign ones, but also the Albania's accession in important international organizations will lead to the creation of permanent arbitration forums and the albanian business will be guided inevitably towards arbitration mechanism for settling commercial disputes. In order to make this happen, there is a necessity to harmonize and approach the domestic legal framework with international contemporary regime in the arbitration field. Such improvement would serve better on business relations and, as consequence, to the economic integration of Albania.

\section{References}

Gary B.Born (1994); "International Commercial Arbitration in the United States: Commentary and Materials"; The Netherlands: Kluwer law and Taxation Publishers.

Stone, Morris; "A Paradox in the Theory of Commercial Arbitration", 21 Arb.Journal. 1966.

Margaret L.Moses (2008); "The Principles and Practice of International Commercial Arbitration”; Cambridge University Press.

Alban Brati (2008); "Civil Procedure", 1st edition; "Dudaj" Editions.

Commentary of the Law "On mediation in resolving disputes" no.10835 dated 24.02.2011, Tirana, 2012; The "Conflict Resolution and Reconciliation of Disputes" Foundation and School of Magistrates of Albania.

Explanatory note by the UNCITRAL Secretariat on the model law on International Commercial Arbitration, UN document noA/40/17 and no.A/61/17, annex I.

UNCITRAL Model Law on International Commercial Conciliation, 2002, United Nations Documents, A/RES/57/18.

UNCITRAL Model Law on International Commercial Arbitration, UN document no.A/40/17 and no.A/61/17.

DIRECTIVE 2008/52/EC of the European Parliament and of the Council of 21 May 2008 "On certain aspects of mediation in civil and commercial matters".

Green Paper "On alternative dispute resolution in civil and commercial law", presented by the Commission; Brussels, 19.04.2002.

Dispute Resolution for the 21st Century, Wipo Arbitration and Mediation Center;

Law no.10385, dated 24.2.2011 "On mediation in resolving disputes".

Law nr.7424, dated 14.11.1990 "On state arbitration".

Law No.8116, dated 29.03.1996, as amended, the Code of Civil Procedure of the Republic of Albania.

Law 7961 dated 12.07.1995, as amended, the Labor Code of the Republic of Albania.

Law no.8687, dated 9.11.2000 "On accession of the Republic of Albania in the "European Convention on International Commercial Arbitration".

Law no.8688 dated 09.11.2000 "On accession of the Republic of Albania in the "Convention on the Recognition and Enforcement of Foreign Arbitral Awards".

The case "Marini vs. Albania", Appeal no.3738/02, Decision 18 December 2007, Strasbourg. 